\title{
Potensi Gen Oncoprotein Human Papillomavirus Tipe 16 Sebagai Kandidat Vaksin Kanker Serviks
}

\author{
Opik Taupiqurrohman, ${ }^{1}$ Muhammad Yusuf, ${ }^{2}$ Sukma Nuswantara, ${ }^{1,3}$ Toto Subroto ${ }^{1,2}$ \\ ${ }^{1}$ Program Studi Bioteknologi, Sekolah Pascasarjana, Universitas Padjadjaran, Bandung, ${ }^{2}$ Departemen Kimia, \\ Fakultas MIPA, Universitas Padjadjaran, Sumedang, ${ }^{3}$ Pusat Penelitian Bioteknologi LIPI Cibinong Bogor
}

\begin{abstract}
Abstrak
Kanker serviks menduduki peringkat dua besar penyebab kematian pada wanita dengan jumlah penderita meningkat setiap tahunnya. Kanker ini banyak diakibatkan oleh infeksi human papillomavirus (HPV) dan tipe prevalensi terbesar di Indonesia adalah tipe HPV 16. Vaksin HPV telah dikembangkan dan diproduksi secara komersial, namun perlu dicari alternatif lain vaksin dengan basis gen penyandi E (early) protein. Gen E6 dan E7 merupakan onkogen penting pada proses terjadinya kanker serviks. Penelitian ini dilaksanakan di Laboratorium Kimia Komputasi dan Bioinformatika, Universitas Padjadjaran, dari bulan Desember 2015 sampai Februari 2016. Pada studi ini, penemuan kandidat vaksin peptida HPV dilakukan dengan pendekatan imunoinformatika. Analisis in silico HPV tipe 16 menunjukkan bahwa gen E7 merupakan sumber kandidat vaksin yang potensial karena tidak homolog dengan genom manusia dan diprediksi memiliki afinitas yang baik terhadap major histocompability complex (MHC). Hasil analisis in silico menunjukkan bahwa kandidat vaksin HPV dari gen E7 adalah peptida YMLDLQPET dan HVDIRTLEDLLMGTL. [MKB. 2016;48(2):84-91]
\end{abstract}

Kata kunci: HPV tipe 16, imunoinformatika, in silico, kanker serviks

\section{Human Papillomavirus Type 16 Oncoprotein Genes as the Candidate of Cervical Cancer Vaccine}

\begin{abstract}
Cervical cancer is the second largest cause of death for Indonesian women, with increasing number of cases every year. This cancer is mostly caused by human papillomavirus (HPV) infection, in which HPV 16 is the most prevalent type in Indonesia. Although HPV vaccine has been developed and commercially available, the other alternative of vaccine based on E (early) gene is required. Genes of E6 and E7 are important oncogenes in the development of cervical cancer. This study was conducted at the Laboratory of Computational Chemistry and Bioinformatics, Universitas Padjadjaran, from December 2015 to February 2016. In this study, the candidates of HPV peptide vaccine were discovered using immunoinformatics method. In silico-analysis of HPV type 16, it was shown gene E7 is not homologous with human genome and it is predicted to have a good affinity with major histocompability complex (MHC). Hence, it was proposed as a potential source of peptide vaccine. It is concluded that he candidates forHPV vaccine from E7 peptides are YMLDLQPET and HVDIRTLEDLLMGTL. [MKB. 2016;48(2):84-91]
\end{abstract}

Key words: Cervical cancer HPV 16, immunoinformatics, in silico

Korespondensi: Opik Taupiqurrohman, S.Si, Program Studi Bioteknologi, Sekolah Pascasarjana Universitas Padjadjaran, Jalan Dipatiukur No.35 Bandung, mobile 081312461370,e-mail opik.taupiqurrohman@yahoo.com 


\section{Pendahuluan}

Kanker serviks merupakan salah satu penyakit dengan tingkat prevalensi tertinggi di dunia, ${ }^{1}$ termasuk di Indonesia. ${ }^{2}$ Di Indonesia kanker serviks saat ini menduduki peringkat dua terbesar penyebab kematian pada wanita dengan jumlah penderita meningkat setiap tahunnya. ${ }^{3}$ Penyakit ini cenderung menyerang wanita pada usia produktif 25-30 tahun. ${ }^{4}$ Saat ini upaya penanggulangan dan pencegahan kanker serviks yang paling efektif adalah vaksin. ${ }^{2}$

Secara epidemiologi, kanker serviks tersebut disebabkan oleh infeksi human papillomavirus (HPV). ${ }^{5}$ HPV tipe 16 merupakan penyebab utama kanker serviks di Indonesia $(60 \%)$ dan di dunia $(45,5 \%){ }^{1}$ Oleh karena itu, HPV tipe 16 perlu diprioritaskan dalam pengembangan vaksinnya. Meskipun vaksin kanker serviks itu sudah diproduksi secara massal, penggunaannya di Indonesia masih terbatas dan juga belum disubsidi oleh pemerintah. ${ }^{6}$ Salah satu hal yang menyebabkan harga vaksin tinggi adalah lama proses pengembangannya yang dapat mencapai 5 sampai 15 tahun. $^{7}$ Saat ini sudah berkembang penemuan kandidat vaksin memakai pendekatan imunoinformatika yang dapat mengefisiensikan tahapan analisis genomik sampai penemuan kandidat vaksin menjadi 1 sampai 2 tahun saja. ${ }^{7}$ Keberhasilan imunoinformatika dalam menemukan peptida yang imunogenik secara in vitro dan in vivo telah dilaporkan. ${ }^{7,8}$

Imunoinformatika merupakan suatu kajian multidisiplin yang telah melibatkan beberapa aspek keilmuan, di antaranya bioinformatika dan juga imunologi. Imunoinformatika tersebut berkembang pesat seiring dengan melimpahnya keterbukaan akses terhadap data genom, di antaranya immunoepitope database (IEDB) ${ }^{9}$ dan Vaxign. ${ }^{10}$ Metode ini dapat membantu penemuan vaksin peptida, yaitu vaksin yang terdiri atas bagian minimal antigen (8-15 asam amino) yang dapat menginduksi sistem imun. ${ }^{13}$ Vaksin peptida memiliki keunggulan dibanding dengan vaksin konvensional dari segi spesifisitas penyakit, kemurnian, kapasitas produksi, dan efisiensi biaya produksi. ${ }^{11}$ Syarat utama pengembangan vaksin melalui imunoinformatika adalah telah tersedianya informasi genom dari patogen target. Saat ini hampir seluruh genom HPV sudah dapat diakses di IEDB. Genom HPV terbagi dalam tiga kategori, yaitu regulator $(10 \%)$, early $(50 \%)$, dan late $(40 \%)$. Gen early terdiri atas $E 1$ sampai $E 7$, sedangkan gen late terdiri atas $L 1$ dan $L 2 .{ }^{15}$ Vaksin kanker serviks yang ada saat ini (Gardasil dan Cervarix) berbasis virus-like particle (VLP) yang dikembangkan dari gen $L 1^{13}$ karena tingkat imunogenisitasnya yang tinggi, sedangkan vaksin berbasis peptida, pengembangannya tidak dibatasi oleh bagian gen tertentu. ${ }^{7}$ Gen onkoprotein E6 dan E7 pada HPV berperan penting dalam inisiasi dan proliferasi sel kanker serviks. Oleh karena itu, E6 dan E7 merupakan target yang menarik dalam pengembangan vaksin HPV. Keunggulan lain dari vaksin peptida adalah hilangnya sifat onkoprotein pada komponen vaksin karena tidak mempergunakan subunit protein utuh. ${ }^{11}$ Mekanisme vaksin peptida dalam menginduksi respons imun adalah melalui interaksinya dengan major histocompatibility complex (MHC), yaitu protein transpor yang bertugas membawa antigen spesifik internal atau eksternal menuju sel $\mathrm{T}^{14}$ Antigen spesifik terdiri atas potongan protein antigen yang dikenal dengan istilah epitop. Sel T terdiri atas tiga jenis, yaitu sel T pembunuh (cytotoxic lymphocytes, CTL), sel T penolong, dan sel $\mathrm{T}$ regulator. CTL berfungsi dalam penghancuran sel yang terinfeksi patogen, sedangkan sel $\mathrm{T}$ penolong berfungsi dalam produksi sitokin yang berperan penting dalam sistem imun. ${ }^{10}$ Terdapat dua kelas MHC, yaitu MHC I dan II. Peptida yang terikat pada MHC I berfungsi mengaktifkan CTL, sementara yang terikat pada MHC II mengaktifkan sel T penolong. Berdasarkan hal tersebut maka prediksi ikatan/ interaksi peptida-MHC perlu dilakukan dalam proses penemuan kandidat vaksin peptida.

Tujuan penelitian ini adalah menemukan kandidat vaksin HPV tipe 16 berbasis peptida/ epitop dari gen E6 dan E7 mempergunakan pendekatan secara imunoinformatika. Analisis homologigen $E 6$ dan $E 7$ terhadap genom manusia dilakukan untuk menyeleksi gen yang berpotensi menimbulkan autoimun. Setelah itu, dilakukan analisis potensi afinitas peptida terhadap MHCI/ II yang diprediksi dapat mengaktivasi sistem imun. Kemudian, interaksi molekular antara peptida kandidat vaksin dan MHCI/II diprediksi dengan metode doking molekular. Penelitian ini diharapkan dapat membantu proses penemuan kandidat vaksin kanker serviks yang lebih efektif dan efisien.

\section{Metode}

Urutan gen E6 dan E7 HPV tipe 16 yang telah ditranslasikan menjadi urutan asam aminonya diperoleh dari Uniprot (http://www.uniprot. org/). Kemudian, analisis homologi urutan asam amino E6 dan E7 terhadap genom manusia 
dilakukan menggunakan program TFASTY.18

Urutan asam amino yang tidak homolog dengan genom manusia diprediksi afinitasnya terhadap MHC menggunakan program IEDBAR. ${ }^{9}$ Varian MHC yang digunakan untuk prediksi afinitas peptida terhadap MHC I dan II adalah alel HLA-A*02:01 dan alel HLA-DBR1*01:01.

Pada pemilihan templat struktur kompleks peptida-MHC dilakukan dengan cara analisis homologi peptida kandidat vaksin terhadap peptida yang terdapat pada struktur kristal di Protein Data Bank (PDB) menggunakan program T-Coffee dan BIOVIA Discovery Studio Visualizer 4.5. Doking molekular dilakukan menggunakan program Cabsdock. ${ }^{16}$ Validasi metode dan juga parameter Cabsdock dilakukan dengan doking ulang enam struktur kristal kompleks MHCpeptida yang diperoleh dari PDB. Dalam tahapan penyiapan struktur MHC, asam amino selain sisi aktif protein tidak dimasukkan pada perhitungan doking molekular.

\section{Hasil}

Analisis homologi gen onkoprotein E6 dan E7 menunjukkan bahwa E6 memiliki persentase keidentikan sebesar 28,91\% dengan genom manusia sehingga gen E6 diprediksi dapat menimbulkan respon autoimun apabila itu digunakan sebagai komponen vaksin peptida. Sementara, gen $E 7$ tidak homolog dengan genom manusia (0\%). Oleh karena itu, hanya gen E7 yang dipilih untuk analisis lebih lanjut dalam penelitian ini.

Prediksi peptida (epitop) yang dapat mengikat MHCI/II pada penelitian ini dilakukan menggunakan program IEDB-AR (immune epitope database analysis resource). ${ }^{9}$ Dalam hasil analisis, peptida dengan peringkat persentil (percentile rank) yang kecil diprediksi memiliki afinitas yang baik dengan MHC. Peringkat persentil mengacu pada persentase skor yang sama atau kurang dari nilai the half maximal inhibitory concentration $\left(\mathrm{IC}_{50}\right)$, yaitu konsentrasi peptida yang menghasilkan nilai $50 \%$ inhibisi MHC. ${ }^{9}$ Pengklasifikasian afinitas hasil prediksi ikatan peptida-MHC pada program IEDB-AR adalah sebagai berikut: tinggi $\left(\mathrm{IC}_{50}<50 \mathrm{nM}\right)$, menengah $(<500 \mathrm{nM})$, dan rendah $(<5000 \mathrm{nM}) .{ }^{9}$

Analisis epitop MHC I dengan IEDB-AR menghasilkan 5 (lima) peptida dengan nilai peringkat persentil terbaik yang ditunjukkan pada Tabel 1. Metode yang digunakan dalam studi ini merupakan konsensus dari tiga metode, yaitu Artificial Neural Network (ANN), Stabilized Matrix Method (SMM), dan juga Combinatory Library Sidney 2008 (comblib_sidney2008). ${ }^{17}$ ANN merupakan algoritma yang terdiri atas kumpulan unit sederhana yang membentuk jaringan komunikasi seperti neuron dalam otak. Unit, yaitu residu MHC I akan memberi respons (nilai $\mathrm{IC}_{50}$ ) apabila ada input signal, yaitu residu peptida. Sementara SMM merupakan metode untuk menghitung matriks afinitas peptida yang terikat pada MHC. Comblib_sidney2008 merupakan metode pengukuran afinitas dari perpaduan berbagai peptida (residu protein yang diuji) terhadap MHC. ${ }^{17}$ Akurasi prediksi menggunakan tiga metode diketahui lebih baik jika dibanding dengan hanya satu metode. ${ }^{9}$

Tabel 1 menunjukkan bahwa peptida yang memiliki afinitas terbaik terhadap MHC I adalah YMLDLQPET dengan nilai peringkat persentil terendah 0,4 dan nilai IC $_{50} 5 \mathrm{nM}$ berdasarkan metode ANN; 20,56 nM berdasarkan metode SMM dan 8,41 x $10^{-5} \mathrm{nM}$ berdasarkan metode comblib_sidney2008.

Analisis epitop MHC II dengan IEDB-AR telah menghasilkan lima peptida dengan nilai peringkat persentil terbaik yang ditunjukkan pada Tabel 2. Dalam prediksi ikatan peptidaMHC II, metode yang dipergunakan adalah konsensus dari 3 metode, yaitu Artificial Neural Network Alignment atau NN-align, Stabilization Matrix Alignment Method (SMM-align), dan Combinatorial Library (Comb.blib). ${ }^{17} \mathrm{NN}$-align mampu memprediksi afinitas peptida terhadap

Tabel 1 Hasil Prediksi Ikatan Peptida-MHC I

\begin{tabular}{|c|c|c|c|c|c|c|c|c|c|}
\hline \multirow{2}{*}{$\begin{array}{l}\text { Gen } \\
H P V\end{array}$} & \multirow{2}{*}{ Alel } & \multicolumn{2}{|c|}{ Posisi Residu } & \multirow{2}{*}{ Panjang } & \multirow{2}{*}{ Peptida } & \multirow{2}{*}{$\begin{array}{l}\text { Peringkat } \\
\text { Persentil }\end{array}$} & \multicolumn{3}{|c|}{ Nilai IC $_{50}(\mathrm{nM})$} \\
\hline & & Awal & Akhir & & & & ANN & SMM & Comblib \\
\hline E7 & HLA-A*02:01 & 11 & 19 & 9 & YMLDLQPET & 0,4 & 5 & 20,56 & $8,41 \times 10^{-5}$ \\
\hline E7 & HLA-A*02:01 & 82 & 90 & 9 & LLMGTLGIV & 0,8 & 19 & 26,13 & $2,37 \times 10^{-5}$ \\
\hline E7 & HLA-A*02:01 & 7 & 15 & 9 & TLHEYMLDL & 2,1 & 48 & 136,18 & $497 \times 10^{-6}$ \\
\hline E7 & HLA-A*02:01 & 85 & 93 & 9 & GTLGIVCPI & 4,4 & 155 & 426,69 & $139 \times 10^{-6}$ \\
\hline E7 & HLA-A*02:01 & 66 & 74 & 9 & RLCVQSTHV & 4,7 & 781 & 208,02 & $532 \times 10^{-6}$ \\
\hline
\end{tabular}


Opik Taupiqurrohman: Potensi Gen Oncoprotein Human Papillomavirus Tipe 16 Sebagai Kandidat Vaksin Kanker Serviks

Tabel 2 Hasil Prediksi Ikatan Peptida-MHC II

\begin{tabular}{|c|c|c|c|c|c|c|c|c|c|}
\hline \multirow{2}{*}{$\begin{array}{l}\text { Gen } \\
\text { HPV }\end{array}$} & \multirow[b]{2}{*}{ Alel } & \multicolumn{2}{|c|}{ Posisi Residu } & \multirow[b]{2}{*}{ Panjang } & \multirow[b]{2}{*}{ Peptida } & \multirow{2}{*}{$\begin{array}{l}\text { Peringkat } \\
\text { Persentil }\end{array}$} & \multicolumn{3}{|c|}{ Nilai Penyejajaran } \\
\hline & & Awal & Akhir & & & & NN & SMM & $\begin{array}{c}\text { comb. } \\
\text { blib }\end{array}$ \\
\hline E7 & $\begin{array}{l}\text { HLA- } \\
\text { DRB1*01:01 }\end{array}$ & 73 & 87 & 15 & HVDIRTLEDLLMGTL & 18,67 & 40,1 & 75 & $4.583,61$ \\
\hline E7 & $\begin{array}{l}\text { HLA- } \\
\text { DRB1*01:01 }\end{array}$ & 76 & 90 & 15 & IRTLEDLLMGTLGIV & 21,79 & 52,3 & 111 & 33,35 \\
\hline E7 & $\begin{array}{l}\text { HLA- } \\
\text { DRB1*01:01 }\end{array}$ & 74 & 88 & 15 & VDIRTLEDLLMGTLG & 23,61 & 60,6 & 73 & $4.583,61$ \\
\hline E7 & $\begin{array}{l}\text { HLA- } \\
\text { DRB1*01:01 }\end{array}$ & 77 & 91 & 15 & RTLEDLLMGTLGIVC & 23,84 & 61,7 & 118 & 33,35 \\
\hline E7 & $\begin{array}{l}\text { HLA- } \\
\text { DRB1*01:01 }\end{array}$ & 72 & 86 & 15 & THVDIRTLEDLLMGT & 23,88 & 61,9 & 92 & $26.863,95$ \\
\hline
\end{tabular}

MHC II dan mengidentifikasi peptida bindingcore, yaitu fragmen peptida yang berinteraksi dengan kantung ikatan utama dari MHC II (binding groove).$^{17}$ Sementara SMM-align merupakan metode prediksi ikatan peptida-MHC II dari pola urutan peptida tertentu yang berdasarkan matriks (position specific weight matrix). Metode comb.lib menggunakan pendekatan pemindaian posisi peptida pada suatu database kombinatorial (positional scanning combinatorial libraries) terhadap kolam peptida acak secara sistematis untuk menentukan kontribusi dari setiap asam amino per sembilan posisi peptida terhadap ikatan peptida-MHC II. Tabel 3 menunjukkan bahwa urutan peptida HVDIRTLEDLLMGTL memiliki afinitas tingkat menengah terhadap MHC II, yaitu dengan nilai $\mathrm{IC}_{50}<500 \mathrm{nM}(\mathrm{NN}-$ align $=40,1 \mathrm{nM}$ dan SMM-align $=75 \mathrm{nM}) \cdot{ }^{18}$ Bagaimanapun, berdasarkan peringkat persentil, urutan tersebut merupakan urutan peptida yang memiliki ikatan paling kuat dengan MHC II di antara urutan peptida hasil prediksi lainnya.

Prediksi epitop MHC berbasis sekuens asam amino sudah dilakukan memakai program IEDBAR, menghasilkan kandidat urutan YMLDLQPET sebagai epitop MHC I dan HVDIRTLEDLLMGTL sebagai epitop MHC II. Interaksi molekular antara kedua kandidat epitop ini dengan MHC dianalisis lebih lanjut mempergunakan metode doking molekular.

Berdasarkan atas keidentikan urutan asam amino, diperoleh 9 (sembilan) struktur kristal MHC I dan tiga struktur kristal MHC II dari PDB. Perbedaan jenis asam amino epitop MHC dapat memengaruhi konformasi rantai samping residu pada sisi aktif MHC. Oleh karena itu, dilakukan analisis homologi peptida kandidat epitop MHC I/II terhadap peptida yang terkompleks dengan struktur kristal MHC. Tahapan ini dilakukan untuk menyeleksi struktur templat terbaik yang dapat digunakan untuk doking molekular. Hasil homologi peptida kandidat epitop MHC I/II dengan peptida MHC I/II dalam struktur kristal menunjukkan bahwa struktur kristal MHC I/ II yang paling sesuai untuk dijadikan templat doking dalam memprediksi interaksi molekular adalah kode PDB 1I4F dan 1AQD dengan persentase keidentikan 20\%.

Validasi metode dan juga parameter doking molekular merupakan suatu tahapan yang perlu dilakukan sebelum analisis interaksi molekular antara kandidat epitop dan MHC I/II. Peptida yang ada dalam struktur kristal MHC I/II didoking ulang untuk mengetahui kemampuan program doking dalam mencari konformasi peptida yang telah ditemukan melalui eksperimen difraksi sinar-X. Suatu program doking dikatakan baik apabila mampu untuk menghasilkan konformasi peptida dengan nilai simpangan (root mean square deviation, RMSD) tidak lebih dari $3 \AA$ terhadap struktur referensinya (struktur kristal peptida). ${ }^{16}$ Dalam penelitian ini, hasil validasi memperlihatkan bahwa nilai RMSD program Cabsdock untuk enam struktur kristal peptidaMHC berada pada rentang antara 0,85 sampai 2,61 Å dengan konformasi peptida hasil doking tersebut berada di binding groove yang sama dengan peptida hasil eksperimen sinar-X. Hal ini menunjukkan bahwa parameter dan metode Cabsdock yang dilakukan memiliki kualitas yang baik. ${ }^{16}$

Setelah metode dan parameter Cabsdock tervalidasi, kemudian dilakukan doking kandidat vaksin epitop terhadap struktur MHC I (kode PDB 1I4F) dan MHC II (kode PDB 1AQD). Interaksi molekular antara peptida kandidat vaksin dan 
Opik Taupiqurrohman: Potensi Gen Oncoprotein Human Papillomavirus Tipe 16 Sebagai Kandidat Vaksin Kanker Serviks

Tabel 3 Interaksi Non-Kovalen antara Asam Amino Peptida YMLDLQPET dan MHC I

\begin{tabular}{|c|c|c|c|}
\hline \multicolumn{2}{|c|}{ Asam Amino } & \multirow{2}{*}{ Jarak (Å) } & \multirow{2}{*}{ Jenis Interaksi } \\
\hline Peptida & MHC & & \\
\hline D185 & K66 & 3,22 & Elektrostatik \\
\hline D185 & R97 & 4,70 & Elektrostatik \\
\hline Y182 & D63 & 3,19 & Elektrostatik \\
\hline Y182 & Y7 & 3,24 & Ikatan hidrogen \\
\hline L184 & R97 & 3,14 & Ikatan hidrogen \\
\hline L184 & R97 & 3,03 & Ikatan hidrogen \\
\hline Y182 & Y99 & 3,13 & Ikatan hidrogen \\
\hline Q187 & Y116 & 3,22 & Ikatan hidrogen \\
\hline L184 & Y99 & 3,75 & Ikatan hidrogen \\
\hline Q187 & $\mathrm{H} 70$ & 3,43 & Ikatan hidrogen \\
\hline M183 & $\mathrm{H} 70$ & 3,39 & Hidrofobik \\
\hline Y182 & Y7 & 5,42 & Hidrofobik \\
\hline M183 & K66 & 5,12 & Hidrofobik \\
\hline M183 & V67 & 5,39 & Hidrofobik \\
\hline L186 & V152 & 5,34 & Hidrofobik \\
\hline P188 & V152 & 4,87 & Hidrofobik \\
\hline L184 & L156 & 5,40 & Hidrofobik \\
\hline L186 & L156 & 5,04 & Hidrofobik \\
\hline L184 & $\mathrm{L} 160$ & 4,85 & Hidrofobik \\
\hline L184 & C164 & 4,64 & Hidrofobik \\
\hline M183 & Y7 & 4,93 & Hidrofobik \\
\hline M183 & Y99 & 5,25 & Hidrofobik \\
\hline L184 & Y99 & 5,25 & Hidrofobik \\
\hline P188 & $\mathrm{H} 114$ & 4,98 & Hidrofobik \\
\hline P188 & W147 & 4,48 & Hidrofobik \\
\hline L184 & Y159 & 5,28 & Hidrofobik \\
\hline Y182 & V34 & 4,61 & Hidrofobik \\
\hline Y182 & M45 & 5,43 & Hidrofobik \\
\hline
\end{tabular}

MHC I/II hasil doking ditunjukkan oleh Gambar 1 dan 2 serta Tabel 3 dan Tabel 4.

Gambar 1 menunjukkan interaksi molekular peptida kandidat vaksin terhadap MHC I dalam rentang jarak 5 Å. Diprediksi terdapat tujuh ikatan hidrogen dan juga delapan belas interaksi hidrofobik (Tabel 3). Ikatan hidrogen konvensional terbentuk antara Y7-Y182, R97-L184, Y99-Y182, dan Q187-Y116. Sementara ikatan hidrogen yang melibatkan donor elektron Pi terbentuk antara residu L184-Y99 dan Q187-H70. Interaksi hidrofobik yang melibatkan gugus alkil terbentuk di antara residu K66-M183, V67-M183, V152-L186, V152-P188, L156-L184, L156-L186, L160-L184, dan juga C164-L184. Interaksi lainnya yang melibatkan orbital sigma-Pi maupun Pi-Pi dibentuk oleh residu H70-M183, Y7-Y182, Y7-M183, Y99-M183, Y99-L184, H114-P188, W147-P188, Y159-L184, Y182-V34, dan Y182-M45. Energi ikatan antara peptida YMLDLQPET dengan MHC I hasil doking diprediksi sebesar $-165,80$. Nilai ini lebih rendah dari energi ikatan antara peptida kristal dan MHC I, yaitu -112,00 sehingga diprediksi bahwa 
Opik Taupiqurrohman: Potensi Gen Oncoprotein Human Papillomavirus Tipe 16 Sebagai Kandidat Vaksin Kanker Serviks

Tabel 4 Interaksi Non-Kovalen antara Asam Amino Peptida HVDIRTLEDLLMGTL dan MHC II.

\begin{tabular}{cccll}
\hline & Asam Amino & & & \multicolumn{1}{c}{ Jenis Interaksi } \\
\hline Peptida & MHC & Jarak (A) & \\
\hline T378 & S51 & 2,64 & Ikatan hidrogen \\
D367 & N60 & 2,96 & Ikatan hidrogen \\
T378 & S51 & 3,28 & Ikatan hidrogen \\
T378 & S51 & 2,58 & Ikatan hidrogen \\
H365 & E202 & 2,88 & Ikatan hidrogen dan jembatan garam \\
L371 & Y252 & 3,32 & Hidrofobik \\
H365 & W235 & 4,69 & Hidrofobik \\
H3655 & W23 & 4,75 & Hidrofobik \\
I368 & R245 & 5,15 & Hidrofobik \\
L379 & V259 & 4,16 & Hidrofobik \\
V366 & L241 & 5,42 & Hidrofobik \\
L374 & F52 & 3,38 & Hidrofobik \\
L374 & A57 & 4,85 & Hidrofobik \\
L374 & F20 & 5,49 & Hidrofobik \\
L379 & F22 & 4,91 & Hidrofobik \\
\hline
\end{tabular}

peptida YMLDLQPET memiliki afinitas yang baik dengan MHC I.

Gambar 2 menunjukkan interaksi molekular peptida kandidat vaksin terhadap MHC II dalam rentang jarak $5 \AA$ A. Diprediksi terdapat lima ikatan hidrogen dan sepuluh interaksi hidrofobik (Tabel 4). Ikatan hidrogen konvensional terbentuk di antara S51-T378, N60-D367, dan T378-S51. Sementara jembatan garam terbentuk antara

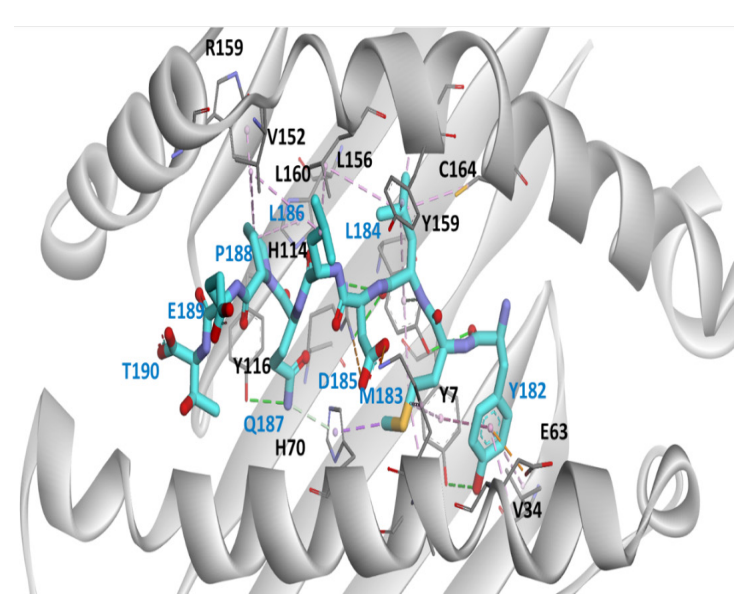

Gambar 1 Interaksi Molekular antara Peptida YMLDLQPET dan MHC I (Kode PDB 1I4F) residu H365-E202. Interaksi hidrofobik yang melibatkan gugus alkil terbentuk di antara residu A57-L374, F20-L374, R245-I368, V259-L379, VL366-L241, dan F22-L379. Interaksi hidrofobik lainnya yang melibatkan orbital sigma-Pi maupun Pi-Pi dibentuk oleh residu L374-F52, L371-Y252, W235-H365, dan H365-W235. Energi ikatan antara peptida HVDIRTLEDLLMGTL dan MHC II hasil doking diprediksi sebesar -164,00. Nilai

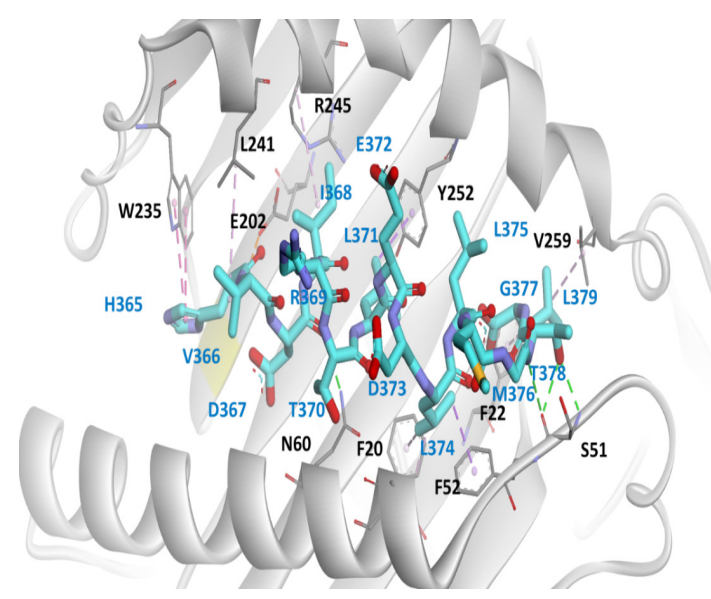
Gambar 2 Interaksi Molekular antara Peptida HVDIRTLEDLLMGTL dan MHC II (Kode PDB 1AQD)


ini lebih tinggi dari energi ikatan antara peptida kristal dan MHC II, yaitu -244,40. Hasil ini sesuai dengan prediksi afinitas HVDIRTLEDLLMGTL terhadap MHC II dari program IEDB-AR. Urutan peptida ini dikategorikan ke dalam epitop dengan afinitas menengah.

\section{Pembahasan}

Selain faktor tingkat homologi gen $E 6$ terhadap genom manusia, rendahnya imunogenisitas gen E6 pada hewan uji juga telah dilaporkan. ${ }^{19}$ Hewan uji yang divaksinasi dengan protein E6 masih memperlihatkan perkembangan sel tumor meskipun yang sangat lambat. ${ }^{19}$ Keadaan ini mengindikasikan bahwa gen E6 kurang potensial untuk dijadikan sebagai komponen vaksin peptida. Sementara, vaksinasi dengan protein E7 pada hewan uji dilaporkan mampu menghambat pertumbuhan sel tumor. ${ }^{19}$ Tabel 2 menunjukkan lima kandidat vaksin peptida potensial yang diprediksi dapat mengaktivasi sel $\mathrm{T}$ sitotoksik ${ }^{20}$ karena memiliki afinitas yang tinggi dengan MHC I. Urutan pertama ditempati oleh YMLDLQPET yang diikuti oleh LLMGTLGIV pada urutan kedua. Menariknya, pada tahun 2015 peptida LLMGTLGIV telah dikonfirmasi mampu mengikat MHC I secara in vitro dengan nilai $\mathrm{BL}_{50}$ (half-maximal binding level) sebesar $5,5 \mu \mathrm{M}^{8}{ }^{50}$ Dengan demikian, peptida YMLDLQPET (urutan pertama) yang diprediksi memiliki nilai IC $_{50}$ lebih baik daripada LLMGTLGIV (urutan kedua), berpotensi untuk menunjukkan afinitas yang tinggi terhadap MHC I.

\section{Ucapan Terima Kasih}

Kami mengucapkan terima kasih kepada IEDB (www.iedb.org) yang telah menyediakan akses terbuka untuk database genom HPV tipe 16 dan program analisis imunoinformatika yang digunakan dalam penelitian ini, serta kepada Dr. Tri Cahyanto, M.Si. dan Dr. Opik Taufikurrahman selaku Ketua Jurusan Biologi dan Dekan Fakultas Sains dan Teknologi UIN Sunan Gunung Djati Bandung yang telah memberikan izin kepada penulis utama untuk melakukan studi lanjut.

\section{Daftar Pustaka}

1. Bruni L, Barrionuevo RL, Albero G, Aldea M, Serrano B, Valencia S, dkk. Human papillomavirus and related diseases in
Indonesia. ICO HPV Information Center; 2015 (diperbaharui 20 Maret 2015; diunduh (27 Desember 2015). Tersedia dari: http:// www.hpvcentre.net/statistics/reports/IDN. pdf.

2. Andrijono. Vaksinasi HPV merupakan pencegahan primer kanker serviks. Maj Kedokt Indon. 2008;57(5):153-8.

3. Kementrian Kesehatan. Jakarta: Kementrian Kesehatan: 2015. [diunduh Oktober 2015] Tersedia dari: http://www.depkes.go.id/ resources/download/pusdatin/infodatin/ infodatin-kanker.pdf.

4. Mzibri ME, Attaleb M, El Hassani RA, Khyatti M, Benbacer L, Ennaji M, dkk. Evaluation of p53, p16INK4a, and E-cadherin status as biomarkers for cervical cancer diagnosis. Intechopen. 2012:12:95-214.

5. Hidayati AN, Evy E, Hans L. Human papillomavirus (HPV) tipe 16 pada lesi genital wanita penderita kondilomata akuminata. Berkala Ilmu Kesehatan Kulit dan Kelamin. 2009;21(1);25-30.

6. Adhi. Perawatpun antusias vaksinasi. [diunduh Maret 2016]. Tersedia dari: http://health.kompas.com/read/2011/08/ 26/13281899/Perawat.Pun.Antusias. Vaksinasi

7. Rappuoli R. Reverse vaccinology. Current Opinion Microbiol. 2000;3:445-50.

8. Li B, Xianfang Z, Chuancui H, Yunxia C. Human papillomavirus genome-wide identification of T-Cell epitopes for peptide vaccine development against cervical cancer: An integration of computational analysis and experimental assay. J Computation Biol. 2015;22(10):962-74.

9. Vita R, Overton JA, Greenbaum JA, Ponomarenko J, Clark JD, Cantrell JR, dkk. The immune epitope database (IEDB) 3.0. Nucleic Acids Res. 2014;43(D1):D405-12.

10. Xiang Z, He Y. Vaxign: a web-based vaccine target design program for reverse Vaccinology. 2009;1:23-9.

11. Toth I, Simerska P, Fujita, Y. Recent advances in design and synthesis of self-adjuvanting lipopeptide vaccines. Int J Pept Res Ther. 2008;14:333-40.

12. Morshed K, Dorota P, Marcin S, Małgorzata P. Human papillomavirus (HPV)-structure, epidemiology and patogenesis. Otolaryngol Pol. 2014;68(5):213-9.

13. Pradita A, Sahiratmadja E, Suhandono S, Susanto H. Sekuens gen protein kapsid mayor L1 human papilomavirus 16 dari isolat klinik asal Bandung. MKB. 2014;46(3):143-9. 
14. Sompayrac L. How the immune system works. Edisi ke-3. Massachussetts: Well Publishing; 2008.

15. Fatima SS, Desu J. Proteome analysis and antigenic peptide prediction of beta corona cirus, a cause of MERS. Helix. 2014;5:590683.

16. Kurcinski M, Michal J, Maciej B, Andrzej K, Sebastian K. CABS-dock web server for the flexible docking of peptides to proteins without prior knowledge of the binding site. Nucleic Acids Research. 2015:1-6.

17. Fleri W. T-cell epitopes-MHC class I binding prediction tools description; T-cell epitopes -MHC class II binding prediction tools description IEDB solutions center [diunduh Februari 2016]. Tersedia dari: http:// help.iedb.org/entries/21903572-t-cell- epitopes-mhc-class-ii-binding-predictiontools-description> dan http://help.iedb. org/entries/21903572-t-cell-epitopes-mhcclass-i-binding-prediction-tools-description 18. Wang P, Sidney J, Kim Y, Sette A, Lund O, Nielsen $M$, dkk. Peptide binding predictions for HLA DR, DP and DQ molecules. BMC Bioinformatics. 2010;11(568):1-12.

19. Li YL, Qiu XH, Shen C, Liu JN, Zhang J. Vaccination of full-length HPV16 E6 or E7 protein inhibits the growth of HPV16 associated tumors. Oncol Report. 2010: 24(5):1323-9.

20. Khallouf H, Agnieszka KG, Angelika BR. Therapeutic vaccine strategies against hman papillomavirus. Vaccine. 2014; 2(2):422-62. 